\section{Verbotene Schlafzone}

Helga Peter

Marburg, Deutschland

\section{Englischer Begriff}

forbidden zone of sleep

\section{Definition}

Bezeichnung für einen Zeitraum von spätnachmittags bis zum frühen Abend, in dem die zirkadian-rhythmisch beeinflusste Einschlafneigung des Menschen ein Minimum aufweist. 